\title{
Studies on Ameliorative Effects of Polyphenolic Extract from Paullinia pinnata L. (Sapindaceae) on Carbon Tetrachloride - Induced Hepatotoxicity and Oxidative Stress: an in vivo Assessment
}

\author{
Mikhail O. NAFIU ${ }^{1}$, Sefiu S. OLANIYI ${ }^{1}$, Musa O. SALAWU ${ }^{1}$, \\ Abdulwakeel A. AJAO ${ }^{2 *}$, Musbau A. AKANJI ${ }^{1}$ \\ ${ }^{1}$ University of Ilorin, Department of Biochemistry, P. M. B. 1515, Ilorin, Nigeria \\ ${ }^{2}$ University of Johannesburg, Department of Botany and Plant Biotechnology, P.O.Box 524, Auckland Park APK, 2006, \\ South Africa; ajwak880@gmail.com (" corresponding author)
}

\begin{abstract}
The current study investigates the effects of polyphenolic extract from the leaf of Paullinia pinnata against $\mathrm{CCl}_{4-}$ induced oxidative stress and liver damage in female albino rats. Thirty albino rats were randomly distributed into six groups (A-F). Rats in group A were given $1 \mathrm{ml}$ normal saline orally to serve as control. The rats in groups $\mathrm{B}, \mathrm{C}, \mathrm{D}, \mathrm{E}$, and $\mathrm{F}$ were respectively induced intraperitoneally with single administration of $1 \mathrm{ml} / \mathrm{kg}$ body weight (b. wt) $\mathrm{CCl}_{4}$ dissolved in liquid paraffin (1:1). Thirty minutes after induction, the rats in the respective groups were orally treated with normal saline, $50 \mathrm{mg} / \mathrm{kg} \mathrm{b}$. wt. Silymarin, 50, 100 and $200 \mathrm{mg} / \mathrm{kg}$ b. wt. polyphenolic extract from $P$. pinnata respectively, once daily for 7 days. Levels of liver function indices and the activities of antioxidant enzymes were determined. Administration of polyphenolic extract from $P$. pinnata significantly $(\mathrm{p}<0.05)$ ameliorated $\mathrm{CCl}_{4}$ induced hepatotoxicity with respect to liver function indices, antioxidant and lipid peroxidation parameters. The biochemical changes observed were also consistent with histopathological observations on the rat liver, as architectural degeneration and severe cellular necrosis were restored after the administration of polyphenolic extract from $P$. pinnata in the treated groups. The study suggests that polyphenolic extract from $P$. pinnata is a potential hepatoprotective agent against $\mathrm{CCl}_{4}$ mediated hepatic injury through fortification of antioxidant defense mechanisms.
\end{abstract}

Keywords: antioxidant; bilirubin; $\mathrm{CCL}_{4}$; hepatotoxicity; globulin; homogenate; serum

\section{Introduction}

Carbon tetrachloride $\left(\mathrm{CCl}_{4}\right)$ induced hepatoxicity is a well known entrenched model characterized by the formation of the trichloromethyl free radical $\left(\mathrm{CCl}_{3}{ }^{*}\right)$ through the action of the mixed function cytochrome $\mathrm{P}_{450}$ oxygenase system of the endoplasmic reticulum, which leads to activation of reactive oxygen species (ROS) in the mitochondria (Boll et al., 2011a). The toxicity progresses through ROS-mediated series of steps including apoptosis, covalent binding of resulting radicals, reductive dehalogenation, inhibition of apolipoprotein synthesis, low and high-density lipoprotein metabolism, fat accumulation, formation of $\mathrm{CCI}_{3}-\mathrm{OO}^{*}$ radicals, lipid peroxidation, membrane damage, loss of $\mathrm{Ca}^{2+}$ sequestration, fibrosis that eventually lead to liver damage (Clawson, 1989; Boll et al., 2011b; Boll et al., 2011c).

Globally, the prevalence of mortality and morbidity associated with liver diseases is increasing at an alarming rate with approximately 29 million people in the European region suffering from a chronic liver damage and more than 30 million Americans having liver diseases. The most common causes of liver diseases worldwide are chronic Hepatitis B and C virus, alcohol and non-alcoholic steatohepatitis associated with obesity and metabolic syndrome (ALF, 2017).

Medicinal plants have been proven to be an effective remedy in the management and treatment of liver diseases without therapeutic adverse effects (Mahmud et al., 2012; Ali et al., 2013; Balamuruganvelu et al., 2014; Sabiu et al., 2015; Sabiu et al., 2016). Thus, significant efforts are being directed towards the searching for plant-based products that can provide efficient succor, accessibility and safer treatments (Umer et al., 2010; Mallhi et al., 2014). In addition, the search must be centered on a medicinal plant that can scavenge ROS and nitric oxide (NO), which are the intermediate products of inflammatory processes and lipid peroxidation during $\mathrm{CCl}_{4}$ mediated toxicity that eventually 
progresses to liver injury (Murugesan et al., 2009). Paullinia pinnata (PP) is one of such botanicals with hepatoprotective potentials based on several pharmacological importance credited to it.

Paullinia pinnata L. is a woody climber (lianas) resident to the tropical rain forest of West Africa. It has pinnate compound leaves hence the specific name 'Pinnata' with five serrated leaflets (Annan et al., 2013). The plant is popularly used in Nigeria and Ghana in the treatment of ailments like sore throat, leprosy liver dysfunction, snake bites, nausea and vomiting (Gill, 1992; Zamble et al., 2006; Jimoh et al., 2007; Nagori et al., 2010; Fred-Jaiyesimi et al., 2011). Previous phytochemical investigation carried out by Yusuff et al. (2014) reported the presence of steroids, triterpenes, alkaloids, saponins, tannins, anthraquinones and flavonoids in the methanol extract. Apart from the fact that $P$. pinnata has been proven pharmacologically to be a good anticancer plant (Tamokou et al., 2013), its methanolic extract has been reported to promote vascular relaxation through its capacity to attenuate nitric oxide oxidation and lipid peroxidation (Zamble et al., 2006).

In view of all the commendable activities of $P$. pinnata associated with ROS scavenging, coupled with its folklore usage in the treatment of liver disorder, with paucity of scientific evidence, hence the current study. The ameliorative effect of polyphenolic-rich extract of Paullinia pinnata against $\mathrm{CCl}_{4-}$ mediated oxidative stress in hepatotoxic rats was evaluated via serum and liver homogenate samples.

\section{Materials and Methods}

Sample collection, authentication, and extract preparation

Fresh $P$. pinnata leaves were collected from Ilofa in OkeEro, Kwara State, Nigeria. Identification and authentication were done in the Department of Plant Biology, University of Ilorin, Nigeria, by Dr. Abdullahi-Alanamu Abdulrahman. Voucher specimen with number UILH/001/1220 was deposited to the Herbarium of the Department.

The leaves were air-dried, pulverized into powder with blender, weighed and kept air-tight prior to extraction. The method of Kim and Lee (2002) was adopted for the extraction of polyphenol from $P$. pinnata: $100 \mathrm{~g}$ of the dried sample was soaked in $400 \mathrm{ml}$ absolute methanol in a beaker. The contents of the beaker were then transferred into a chilled blender and immediately macerated by for 3 mins. The homogenized sample was transferred into a beaker containing $50 \mathrm{ml}$ of $80 \%$ aqueous methanol and placed in an ice bath using a polytron homogenizer for 2 mins and filtered with Whatman No 1 filter paper. The residue was then transferred back to the polytron homogenizer with $100 \mathrm{ml}$ of the residue for maceration and filtration. The filtrates were combined and concentrated using a rotatory evaporator.

\section{Determination of total phenolic content}

This was determined using Folin-Ciocalteau assay as described by Danilewicz (2015). Briefly, triplicate samples of $10 \mathrm{mg} / \mathrm{ml}$ of PEPP extract was dissolved in methanol and then added to $2.9 \mathrm{ml}$ of $2 \% \mathrm{Na}_{2} \mathrm{CO}_{3}$. The solution was then allowed to stand for $2 \mathrm{~min}$ at room temperature before adding $0.1 \mathrm{ml}$ of $0.2 \mathrm{~N}$ Folin-Ciocalteau reagent to the solution. The resulting mixtures were then incubated for 30 min at room temperature. The absorbance of the reaction mixtures was taken spectrophotometrically at $750 \mathrm{~nm}$. Gallic acid (0.1-1.0 mg/ml methanol) was used as a standard and the total phenolic contents of the extract were expressed in milligram gallic acid equivalents (mg gallic acid/g extract).

\section{Experimental animals}

Thirty (30) female albino rats (Rattus novergicus) (150$230 \mathrm{~g}$ ) were obtained from the Animal Holding Unit of the Department of Biochemistry, University of Ilorin, Ilorin, Nigeria. The rats were allowed to acclimatize for 7 days in the laboratory under standard conditions (12-hours light/dark cycle, $25 \pm 2{ }^{\circ} \mathrm{C}$ photoperiod). They were fed with standard rodent diet and tap water ad libitum in accordance with the guidelines of National Research Council Guide for the Care and Use of Laboratory animals as described by Mansour et al. (2017). The study was conducted with the Approval (UIL/2016/0009) of the University of Ilorin Ethical Committee on the Use and Care of Laboratory Animals

\section{Induction of hepatotoxicity and animal grouping}

$\mathrm{CCl}_{4}$-induced hepatotoxicity was done by intraperitoneally injecting $1 \mathrm{ml} / \mathrm{kg} \mathrm{b}$. w. $\mathrm{CCl}_{4}$ dissolved in liquid paraffin in ratio 1:1 after animals are being denied food for 18 hours. The rats were randomly divided into six groups of five rats each.

Group A served as normal control and were administered $1 \mathrm{ml} / \mathrm{kg}$ normal saline.

Group B served as hepatotoxic control rats treated with normal saline.

Group C served as $\mathrm{CCl}_{4}$-induced hepatotoxic treated rats with $50 \mathrm{mg} / \mathrm{kg}$ Silymarin as reference drug.

Group D served as $\mathrm{CCl}_{4}$.induced hepatotoxic rats treated with $50 \mathrm{mg} / \mathrm{kg}$ b.w polyphenolic-rich extract of Paulliniapinnata (PEPP).

Group E served as $\mathrm{CCl}_{4}$ induced hepatotoxic rats treated with $100 \mathrm{mg} / \mathrm{kg}$ b.w PEPP.

Group $\mathrm{F}$ served as $\mathrm{CCl}_{4}$.induced hepatotoxic rats treated with $200 \mathrm{mg} / \mathrm{kg}$ b.w PEPP.

\section{Serum preparation and excision of the liver}

Twenty-four hours after the administration of the last dose, the rats were anaesthetized with diethyl ether and sacrificed by simply cutting the jugular vein; the blood samples were collected into heparinized and plain sample tubes for haematological and serum analysis respectively. Blood samples for serum were left to stand at room temperature for $30 \mathrm{mins}$ to clot after which it was centrifuged at 3,000 rpm for 10 mins. The serum was collected using a Pasteur's pipette, appropriately labelled and stored in a freezer at $-20{ }^{\circ} \mathrm{C}$. The rats were then dissected and the livers were removed, cleansed of superficial connective tissue and the transferred into ice-cold $0.25 \mathrm{M}$ sucrose solution. The tissues were minced finely with dissecting knife and homogenized in ice-cold $0.25 \mathrm{M}$ sucrose solution $(1: 5 \mathrm{w} / \mathrm{v})$ using pre-cooled mortar and 
pestle in a bottle of ice. The homogenates were stored frozen overnight before centrifuging (Akanji and Ngaha, 1989). The homogenates were centrifuged at $800 \mathrm{~g}$ for $10 \mathrm{~min}$ at 4 ${ }^{\circ} \mathrm{C}$; the resulting supernatant was aspirated with Pasteur pipette into sample bottles and kept frozen at $-20{ }^{\circ} \mathrm{C}$ to ensure maximum release of the enzymes before being used for the determination of various biochemical parameters.

\section{Liver function parameters and antioxidant analyses}

Prior to the determination of metabolites and enzyme activities, the tissue homogenates were diluted using $0.25 \mathrm{M}$ sucrose solution. Liver function parameters were determined by strictly following the manufacturer's instructions on the use of the assay kits. The concentrations of serum albumin, bilirubin, globulin and protein were determined by adopting the methods of Sherlock (1951), Doumas et al. (1971), Plummer (1978) and Tietz (1995). Other activities for both serum and homogenate such as alkaline phosphatase (ALP) was evaluated following Wright et al. (1972); alanine aminotransferase (ALT), aspartate aminotransferase (AST) following Reitman and Frankel (1957) and Schmidt and Schmidt (1963). Gamma-glutamyl transferase (GGT) assay was carried out following Szasz (1974). The antioxidant and lipid peroxidation makers including catalase (CAT), superoxide dismutase (SOD) and were assayed by adopting the methods of Beers and Sizer (1952), Marklund and Marklund (1974) and Reilly and Aust (2001).

\section{Histological analysis}

Liver specimens were fixed in $10 \%$ formalin. The specimens were dehydrated in ascending grades of ethanol, cleared in xylene and processed to paraffin blocks, sectioned ( $5 \mu \mathrm{m}$ thick) and stained with Hematoxyline and Eosin stain. They were examined using light microscopy for a demonstration of hepatic pathological changes including degeneration of $\beta$-cell of Langerhans, atrophy, cell destruction, necrosis and the efficiency of a polyphenolic extract of Paullinia pinnata leaf to ameliorate these pathological features (Drury and Wallington, 1980).

\section{Statistical analysis}

The data were analysed by one-way analysis of variance (Statistical Analysis System (SAS) Model 9.13) complemented by Duncan's Post Hoc test to detect significant differences. All data were expressed as the mean of five replicates \pm Standard Error of Mean (S.E.M). Values were considered statistically significant at $p<0.05$ (confidence level $=95 \%$ ).

\section{Results}

The total polyphenolic content of the methanolic extract of $P$. pinnata expressed as Gallic acid equivalent (GAE) was $150 \mathrm{mg} \mathrm{GAE} / \mathrm{g}$. The percentage of organ-body weight ratio revealed no significant difference in liver weight to body ratio between the hepatotoxic groups administered PEPP and the control at $p>0.05$ (Table 1). The effects of PEPP on serum activities of liver function enzymes (Table 2). A significant increase $(p>0.05)$ in ALP and AST was obtained in the treated group for all the dosages administered to the rats when compared with those that received Silymarin and normal control. However, significant increase ALT activity was noted only in rats treated with $200 \mathrm{mg} / \mathrm{kg}$ b.w PEPP compared with other groups. A significant increase in GGT was observed in the treated rats that received $50 \mathrm{mg} / \mathrm{kg} \mathrm{b}$. w. PEPP with the other treated groups and the control.

The effects of PEPP on the activities of liver function enzymes are presented in Table 3. For ALP, the treated rats that were administered $100 \mathrm{mg} / \mathrm{kg}$ dose of PEPP compete favourably with the control in the increment of the enzyme at $\mathrm{p}<0.05$; however, the best activity was observed in the highest administered dosage. The same trend was observed in ALT and AST where a significant increase was observed in the activity of the enzyme of the treated rats in all doses administered when compared with the rats that were treated with normal saline. In addition, the rats that were administered $100 \mathrm{mg} / \mathrm{kg}$ dose of PEPP elicited proportional increment with the normal control for the activity of GGT enzyme.

The effects of PEPP on some liver function indices are presented in Table 4. A significant increase $(p<0.05)$ in albumin and total protein was observed in the rats treated PEPP when compared with the hepatotoxic. However, the rats that were administered the highest dosage of PEPP compared favourably with those that received standard drug (Silymarin). For direct bilirubin, the rats that were administered PEPP at all dosages elicited significant reduction when compared with hepatotoxic control. In addition, the rats that were administered $200 \mathrm{mg} / \mathrm{kg}$ of PEPP competes favourably with the normal control in the increment of globulin, while a significant reduction was also observed in total bilirubin in the treated group when compared with hepatotoxic control.

The effects of polyphenolic extract of Paullina pinnata on antioxidant enzymes activity and liver malonaldehyde content of $\mathrm{CCl}_{4}$-treated rats are presented in Table 5. A significant increase in the activities of SOD and CAT were obtained in all the PEPP treated rats at all dosages when

Table 1. Effects PEPP on liver to body weight ratio of $\mathrm{CCl}_{4}$-treated hepatotoxic rats

\begin{tabular}{ccc}
\hline Treatments & Dose & Organ to weight $(\%)$ \\
\hline Control + Normal saline (NS) & $1.00 \mathrm{ml}$ & $2.66 \pm 0.18^{\mathrm{a}}$ \\
\hline $\mathrm{CCl}_{4}-$ Induced + NS & $1.00 \mathrm{ml}$ & $3.12 \pm 0.45^{\mathrm{a}}$ \\
\hline $\mathrm{CCl}_{4}$-Induced + Silymarin & $50 \mathrm{mg} / \mathrm{kg} \mathrm{b.w}$ & $2.9 \pm 0.15^{\mathrm{a}}$ \\
$\mathrm{CCl}_{4}$-Induced + PEPP & $50 \mathrm{mg} / \mathrm{kg} \mathrm{b.w}$ & $3.40 \pm 0.38^{\mathrm{a}}$ \\
$\mathrm{CCl}_{4}$-Induced + PEPP & $100 \mathrm{mg} / \mathrm{kg} \mathrm{b.w}$ & $2.67 \pm 0.35^{\mathrm{a}}$ \\
$\mathrm{CCl}_{4}$-Induced + PEPP & $200 \mathrm{mg} / \mathrm{kg} \mathrm{b.w}$ & $2.95 \pm 0.16^{\mathrm{a}}$
\end{tabular}

Values are expressed as means of 5 replicates \pm SEM. Values with the same superscript along the column are not significantly different $(\mathrm{p}<0.05)$. 
Table 2. Effect of PEPP on serum activities of liver function enzymes of CCl4-treated hepatotoxic rats

\begin{tabular}{|c|c|c|c|c|}
\hline Treatments & $\operatorname{ALP}(\mathrm{U} / \mathrm{I})$ & $\operatorname{ALT}(\mathrm{U} / \mathrm{I})$ & $\operatorname{AST}(\mathrm{U} / \mathrm{I})$ & $\mathrm{GGT}(\mathrm{U} / \mathrm{I})$ \\
\hline Control & $30.82 \pm 1.11^{a}$ & $29.94 \pm 0.59^{a}$ & $5.86 \pm 0.64^{\mathrm{a}}$ & $5.19 \pm 0.58^{\mathrm{a}}$ \\
\hline $\mathrm{CCl}_{4}$ treated & $175.73 \pm 13.64^{b}$ & $44.65 \pm 1.52^{b}$ & $36.35 \pm 0.97^{b}$ & $22.01 \pm 1.61^{\mathrm{b}}$ \\
\hline $\mathrm{CCl}_{4}+$ Silymarin $(50 \mathrm{mg} / \mathrm{kg} \mathrm{b}$. wt $)$ & $44.18 \pm 0.75^{a}$ & $36.52 \pm 0.80^{c}$ & $7.89 \pm 0.40^{c}$ & $6.49 \pm 0.79^{a c}$ \\
\hline $\mathrm{CCl}_{4}+50 \mathrm{mg} / \mathrm{kg}$ b.wt PEPP & $73.70 \pm 4.24^{\mathrm{d}}$ & $38.00 \pm 0.33^{c}$ & $21.90 \pm 0.55^{\mathrm{d}}$ & $11.63 \pm 1.61^{\mathrm{d}}$ \\
\hline $\mathrm{CCl}_{4}+100 \mathrm{mg} / \mathrm{kg}$ b.wt PEPP & $47.07 \pm 7.89^{\mathrm{ac}}$ & $32.00 \pm 0.16^{\mathrm{a}}$ & $19.00 \pm 0.53^{\mathrm{e}}$ & $5.78 \pm 1.49^{\mathrm{ac}}$ \\
\hline $\mathrm{CCl}_{4}+200 \mathrm{mg} / \mathrm{kg}$ b.wt PEPP & $66.12 \pm 2.8^{\mathrm{cd}}$ & $35.90 \pm 0.66^{c}$ & $20.76 \pm 0.48^{\text {de }}$ & $9.52 \pm 0.8^{\text {cd }}$ \\
\hline
\end{tabular}

Values are expressed as means of 5 replicates \pm SEM. Values with the same superscript along the column are not significantly different $(\mathrm{p}<0.05)$. ALP: alkaline phosphatase; ALT: alanine aminotransferase;AST: aspartate aminotransferase; GGT: gamma glutamyl transferase.

Table 3. Effect of PEPP on homogenate activities of liver function enzymes of CCl4-treated hepatotoxic rats

\begin{tabular}{|c|c|c|c|c|}
\hline Treatments & $\operatorname{ALP}(\mathrm{U} / \mathrm{I})$ & $\operatorname{ALT}(\mathrm{U} / \mathrm{I})$ & $\operatorname{AST}(\mathrm{U} / \mathrm{I})$ & GGT $(\mathrm{U} / \mathrm{I})$ \\
\hline Control & $218.42 \pm 4.68^{\text {ad }}$ & $559.00 \pm 3.15^{\mathrm{a}}$ & $473.13 \pm 14.40^{2}$ & $69.97 \pm 2.72^{a}$ \\
\hline $\mathrm{CCl}_{4}$ treated & $139.73 \pm 19.72^{\mathrm{b}}$ & $121.85 \pm 0.48^{b}$ & $34.07 \pm 0.45^{b}$ & $42.55 \pm 3.06^{b}$ \\
\hline $\begin{array}{l}\mathrm{CCl}_{4}+\text { Silymarin } \\
(50 \mathrm{mg} / \mathrm{kg} \text { b. wt })\end{array}$ & $362.23 \pm 27.30^{c}$ & $309.60 \pm 8.44^{\mathrm{c}}$ & $189.31 \pm 1.04^{\mathrm{c}}$ & $59.71 \pm 2.73^{c}$ \\
\hline $\mathrm{CCl}_{4}+50 \mathrm{mg} / \mathrm{kg}$ b.wt PEPP & $243.85 \pm 53.77^{\mathrm{d}}$ & $243.48 \pm 0.42^{\mathrm{d}}$ & $79.35 \pm 3.70^{d}$ & $51.43 \pm 3.07^{\mathrm{d}}$ \\
\hline $\begin{array}{c}\mathrm{CCl}_{4}+100 \mathrm{mg} / \mathrm{kg} \\
\text { b.wt PEPP }\end{array}$ & $222.51 \pm 25.83^{\text {ad }}$ & $329.17 \pm 2.01^{\mathrm{e}}$ & $136.96 \pm 9.28^{\mathrm{e}}$ & $61.56 \pm 3.03^{2}$ \\
\hline $\begin{array}{c}\mathrm{CCl}_{4}+200 \mathrm{mg} / \mathrm{kg} \\
\text { b.wt PEPP }\end{array}$ & $271.78 \pm 12.99^{\mathrm{d}}$ & $272.56 \pm 8.24^{f}$ & $112.50 \pm 5.10^{f}$ & $52.17 \pm 2.21^{\mathrm{d}}$ \\
\hline
\end{tabular}

Values are expressed as means of 5 replicates \pm SEM. Values with the same superscript along the column are not significantly different $(\mathrm{p}<0.05)$. ALP: alkaline phosphatase; ALT: alanine aminotransferase;AST: aspartate aminotransferase; GGT: gamma glutamyl transferase.

Table 4. Effects of polyphenolic extract of Paullinia pinnata leafs on some liver function indices of CCl4-treated hepatotoxic rats

\begin{tabular}{|c|c|c|c|c|c|}
\hline Treatments & Albumin $(\mathrm{g} / \mathrm{l})$ & DBIL (umol/l) & Globulin $(\mathrm{g} / \mathrm{l})$ & TBIL (umol/l) & T. protein $(\mathrm{mg} / \mathrm{ml})$ \\
\hline Control & $54.71 \pm 5.02^{\mathrm{a}}$ & $17.23 \pm 0.01^{\mathrm{a}}$ & $5.18 \pm 0.10^{a}$ & $13.88 \pm 0.53^{a}$ & $59.89 \pm 4.95^{\mathrm{a}}$ \\
\hline $\mathrm{CCl}_{4}$ treated & $12.23 \pm 1.79^{b}$ & $53.51 \pm 1.28^{b}$ & $4.68 \pm 0.22^{\mathrm{ab}}$ & $85.79 \pm 5.00^{b}$ & $16.90 \pm 1.58^{b}$ \\
\hline $\begin{array}{l}\mathrm{CCl}_{4}+\text { Silymarin } \\
(50 \mathrm{mg} / \mathrm{kg} \text { b. wt })\end{array}$ & $32.39 \pm 0.55^{c}$ & $25.22 \pm 1.07^{\mathrm{c}}$ & $4.33 \pm 0.23^{\mathrm{b}}$ & $38.62 \pm 1.90^{c}$ & $36.72 \pm 0.34^{\mathrm{c}}$ \\
\hline $\mathrm{CCl}_{4}+50 \mathrm{mg} / \mathrm{kg}$ b.wt PEPP & $16.35 \pm 0.58^{b}$ & $42.44 \pm 1.91^{\mathrm{d}}$ & $4.93 \pm 0.23^{\mathrm{ab}}$ & $64.06 \pm 1.22^{\mathrm{d}}$ & $21.28 \pm 0.69^{b}$ \\
\hline $\mathrm{CCl}_{4}+100 \mathrm{mg} / \mathrm{kg}$ b.wt PEPP & $23.85 \pm 1.43^{\mathrm{d}}$ & $31.37 \pm 1.07^{\mathrm{e}}$ & $4.86 \pm 0.18^{\mathrm{ab}}$ & $46.71 \pm 2.46^{e}$ & $28.71 \pm 1.31^{\mathrm{d}}$ \\
\hline $\mathrm{CCl}_{4}+200 \mathrm{mg} / \mathrm{kg}$ b.wt PEPP & $36.37 \pm 1.34^{\mathrm{c}}$ & $44.28 \pm 1.51^{\mathrm{d}}$ & $5.16 \pm 0.15^{\mathrm{a}}$ & $65.91 \pm 2.12^{\mathrm{d}}$ & $41.53 \pm 1.33^{c}$ \\
\hline
\end{tabular}

Values are expressed as means of 5 replicates \pm SEM. Values with the same superscript along the column are not significantly different $(\mathrm{p}<0.05)$. T. protein: Total Protein; TBIL: Total Bilirubin; DBIL: Direct Bilirubin.

Table 5. Effects of PEPP on antioxidant enzymes activity and liver malonaldehyde content of $\mathrm{CCl}_{4}$-treated rats

\begin{tabular}{cccc}
\hline Treatments & CAT $(\mathrm{U} / \mathrm{min} / \mathrm{mg}$ protein $)$ & SOD $(\mathrm{U} / \mathrm{min} / \mathrm{mg}$ protein $)$ & $\mathrm{MDA}) \times 10^{4}(\mathrm{nmol} / \mathrm{ml})$ \\
\hline Control & $248.34 \pm 10.28^{\mathrm{a}}$ & $3.32 \pm 0.03^{\mathrm{a}}$ & $4.67 \pm 0.50^{\mathrm{a}}$ \\
\hline $\mathrm{CCl}$ treated & $63.2591 \pm 13.45^{\mathrm{b}}$ & $0.56 \pm 0.09^{\mathrm{b}}$ & $8.56 \pm 0.37^{\mathrm{b}}$ \\
$\mathrm{CCl}_{4}+\mathrm{Silymarin}(50 \mathrm{mg} / \mathrm{kg} \mathrm{b.} \mathrm{wt})$ & $218.31 \pm 9.27^{\mathrm{c}}$ & $2.48 \pm 0.03^{\mathrm{cd}}$ & $6.46 \pm 0.48^{\mathrm{a}}$ \\
$\mathrm{CCl}_{4}+50 \mathrm{mg} / \mathrm{kg}$ b.wt PEPP & $142.02 \pm 10.43^{\mathrm{d}}$ & $1.79 \pm 0.01^{\mathrm{e}}$ & $4.80 \pm 0.22^{\mathrm{a}}$ \\
$\mathrm{CCl}_{4}+100 \mathrm{mg} / \mathrm{kg}$ b.wt PEPP & $212.87 \pm 9.62^{\mathrm{c}}$ & $2.36 \pm 0.04^{\mathrm{c}}$ & $5.46 \pm 0.15^{\mathrm{a}}$ \\
$\mathrm{CCl}_{4}+200 \mathrm{mg} / \mathrm{kg}$ b.wt PEPP & $204.01 \pm 6.10^{\mathrm{c}}$ & $2.60 \pm 0.07^{\mathrm{d}}$ & $5.23 \pm 0.28^{\mathrm{a}}$ \\
\hline
\end{tabular}

Values are expressed as means of 5 replicates \pm SEM. Values with the same superscript along the column are not significantly different $(\mathrm{p}<0.05)$

compared with the hepatotoxic control and also compete favourably with Silymarin treated rats. Contrary, to the results of CAT and SOD activities, significant decrease was noted in lipid peroxidation enzyme (MDA) in the PEPP treated rats when compared with the hepatotoxic rat and compared favourably with the normal control at $\mathrm{p}>0.05$.

Photomicrographs of the liver of normal control and $\mathrm{CCl}_{4}$ hepatotoxic control and treated rats are shown in Fig. 1. Microscopic observation of the liver of the normal control rats showed the normal architecture, where the central veins, portal tracts, hepatocytes and sinusoids appeared normal (Fig. 1A). On the contrary, Fig. 1B showed the histological structure of the hepatotoxic control with severe patchy and confluent hepatocyte necrosis of the hepatocyte, lobular inflammation and distortion of liver architecture. The sinusoidal spaces were also flooded with inflammatory cells. Furthermore, the hepatotoxic rats treated with the Silymarin showed normal lobular pattern (Fig. 1C). In Fig. 1D, there are moderate cellular necrosis in the architecture of the liver in the rats that were administered $50,100 \mathrm{mg} / \mathrm{kg}$ dose of PEPP, while moderate cellular degeneration and vascular congestion were observed in the liver section of the rats treated with $100 \mathrm{mg} / \mathrm{kg}$ dose of PEPP (Fig. 1E). Lastly, moderate hepatocytes that are devoid of necrosis were evident in the hepatotoxic group treated with $200 \mathrm{mg} / \mathrm{kg}$ dose of PEPP (Fig. 1F). 

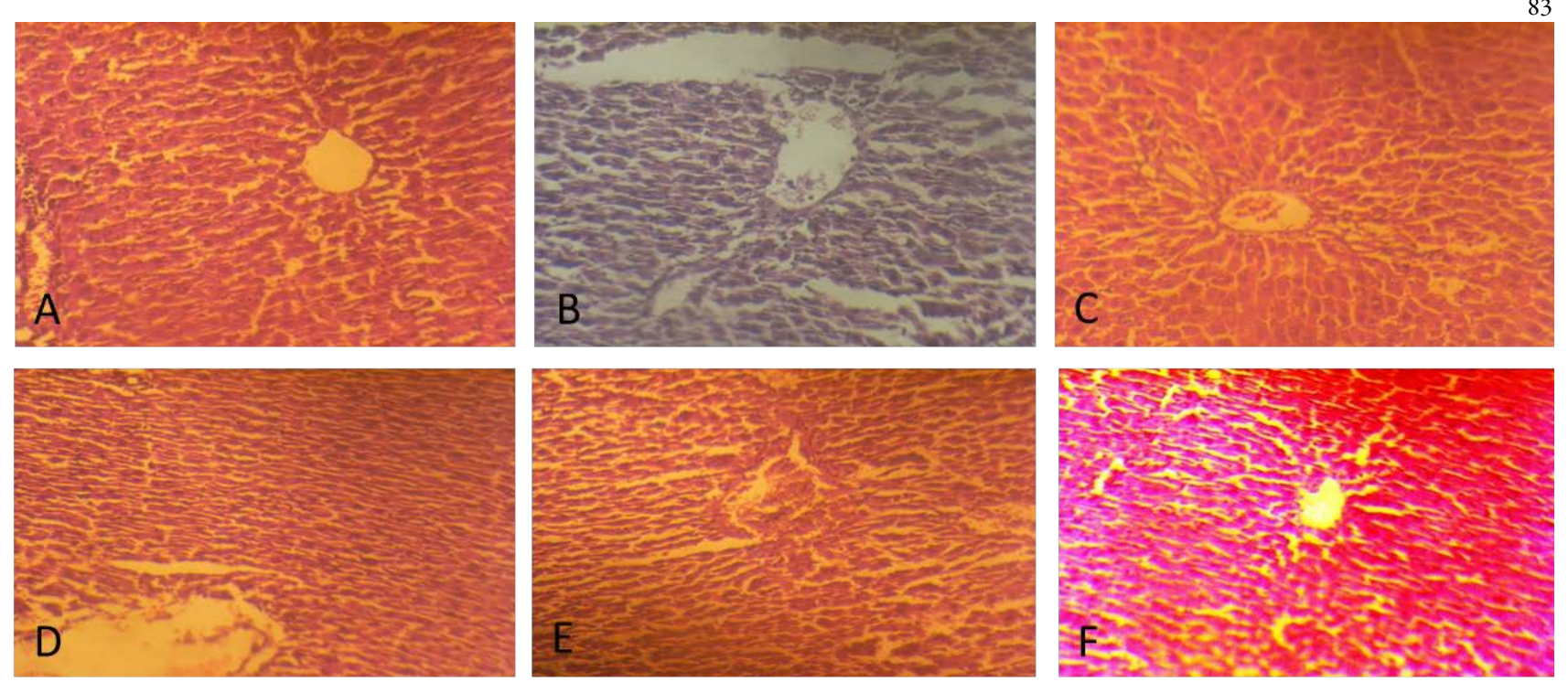

Fig. 1. Photomicrograph of the effect of administration of PEPP on the histology of the liver; (A) Normal control; (B) Hepatotoxic control; (C) Hepatotoxic treated with Silymarin; (D) Hepatotoxic treated with with $50 \mathrm{mg} / \mathrm{kg}$ b.w PEPP; (E) Hepatotoxic treated with $100 \mathrm{mg} / \mathrm{kg}$ b.w PEPP; (F)Hepatotoxic treated with $200 \mathrm{mg} / \mathrm{kg}$ b.w PEPP

\section{Discussion}

The menace of drug-induced liver injury is a major challenge to researchers globally. $\mathrm{CCl}_{4}$-induced hepatotoxicity is known to be prompted by oxidative stress through bioactivation of the phase I cytochrome P450 system to form reactive metabolic trichloromethyl radicals $\left({ }^{*} \mathrm{CCl}_{3}\right)$ and peroxy trichloromethyl radicals $\left({ }^{*} \mathrm{OOCCl}{ }_{3}\right)$ (Ogeturk et al., 2005; Jaramillo-Juarez et al., 2008). The increased lipoperoxide and free peroxide radical concentrations lead to elevation of cytosolic AST, ALT, ALP and GGT in the body system, and are used in the evaluation of drug-induced hepatotoxicity (Jaeschke et al., 2003). In the current study, the increased activity of these marker enzymes in the $\mathrm{CCl}_{4}$ induced rats was indicative of cellular necrosis and hepatotoxicity. This assertion has been canvassed in previous studies (Khan et al., 2012; Adewale et al., 2014; Somnath et al., 2017), where administration of $\mathrm{CCl}_{4}$ caused liver damage. However, the significant reduction in the specific activity of these enzymes in the rats treated with PEPP is suggestive of the amelioration of the effects of $\mathrm{CCl}_{4}$ with no observable adverse effect on the organ as there was no significant difference $(p>0.05)$ in liver weight after the treatment.

Plant-based metabolite such as polyphenols has been extensively used in the treatment of array of disorders including diabetes and liver steatosis (Aguirre et al., 2004; Büyükbalci and El, 2008). It is one of the most important components of human diet due to its ability to mop-up and inhibits further generation of ROS which accounts for its several pharmacological activities (Laight, 2000). Elevated transaminase, such as ALT and AST, activities are known marker for hepatocyte injury mediated by ROS via oxidative stress (Contreras-Zentella and Hernández-Muñoz, 2016). GGT is a specific biomarker of hepatobiliary injury, especially cholestasis and biliary effects (Sheehan and Haythorn, 1979), while ALP is a marker enzyme for the plasma membrane and endoplasmic reticulum (Wright and Plummer, 1974). The elevated levels of these biochemical parameters are a direct reflection of alterations in the hepatic structural integrity (Patrick-Iwanyanwu et al., 2010). In the present study, the $\mathrm{CCl}_{4}$ mediated a significant increase in serum ALP, ALT, GGT and AST in the rats. The elevated GGT, ALT and AST in the $\mathrm{CCl}_{4}$-treated group were significantly reduced upon treatment with Silymarin, the reference drug and PEPP indicating ameliorative effect from the toxicant. It was observed that the extract significantly normalized the elevated ALT and AST across the treatment groups especially at $100 \mathrm{mg} / \mathrm{kg}$ and $200 \mathrm{mg} / \mathrm{kg}$ dose levels. Although, $50 \mathrm{mg} / \mathrm{kg}$ dose of the PEPP seems to be below the therapeutic dosage needed to condition the hepatocytes or protect them from an impending liver damage. $\mathrm{CCl}_{4}$-treated rats also showed elevated ALP activity which was significantly lowered by the extract. High level of ALP is an indicator of obstructive jaundice and intra-hepatic cholestasis (Adebayo et al., 2003).

The concentrations of albumin, globulin and bilirubin in the serum is a well-known index to determine the secretory and synthetic functioning of the liver and can be used to ascertain types of liver damage (Yakubu et al., 2003). The significantly elevated concentration of bilirubin in the serum of hepatotoxic rats could be due to $\mathrm{CCl}_{4}$-mediated hepatoxicity which occurs as result of bilirubin uptake obstruction and its secretion into bile (Sabiu et al., 2015). Therefore, the significant increase in serum albumin, serum globulin and serum total protein coupled with the attenuation in the level of bilirubin in the PEPP-treated rats is an indicator of enhanced synthetic, secretory and excretory functions of the hepatocytes facilitated by PEPP. The overall activity elicited by PEPP is a reference proof for the ameliorative potential of PEPP leaves against damage by $\mathrm{CCl}_{4}$. The present observations concur with the earlier reports of Adewale et al. (2014) where attenuation of bilirubin level was observed in hepatotoxic rats following administration of Xylopia aethiopica extract. This thus suggests that PEPP has the ability to promote the efficiency of the the liver by activating the constitutive androstane receptor (CAR) which is a key regulator for bilirubin clearance in the liver (Moore and Dalley, 1999). 
84

Free radicals scavenging enzymes are first line cellular defense against oxidative stress, dissipating $\mathrm{O}_{2}$ and $\mathrm{H}_{2} \mathrm{O}_{2}$ before their interaction to form dangerous hydroxyl $(\mathrm{OH})$ radical which can lead to cell death (Lil et al., 1988). Therefore, the reduction in the activity of these enzymes may result in a number of deleterious effects due to the accumulation of superoxide radicals and hydrogen peroxide. The observed decrease in antioxidant enzymes (CAT and SOD) following exposure of rats $\mathrm{CCl}_{4}$ may be due to induction of the nuclear factor kappa $\mathrm{B}$ (NF- $\mathrm{kB}$ ) activation and its translocation, which are responsible for modulation of liver injury (Ma et al., 2014; Ma et al., 2015). It may also be as a result of elevated nitric oxide (NO) through activation of iNOS (Tipoe et al., 2006). This finding is consistent with the report of Szymonik-Lesiuk et al. (2003) and $\mathrm{Wu}$ et al. (2017) where a similar reduction in antioxidant enzymes was observed following the administration of $\mathrm{CCl}_{4}$. However, the reversal in $\mathrm{CCl}_{4}-$ induced oxidative stress as evident in the elevation of SOD and CAT following administration of PEPP is implicative of its antioxidative capability, which can be attributed to the ability of the extract to scavenge ROS in the liver.

Lipid peroxidation products are formed when reactive oxygen species attack polyunsaturated fatty acids, leading to loss of membrane integrity vis-à-vis structural functions (Yoshida et al., 2013). Therefore, the significant increase in MDA observed in the hepatoxic rat may depict haphazard oxidative onslaughts of $\mathrm{CCl}_{4}$ on membrane-bound lipids which may in turn, disrupt the membrane integrity in terms of fluidity and architecture (Niki, 2009). The restoration of the membrane integrity through attenuation of $\mathrm{CCl}_{4-}$ induced peroxidative materials by PEPP is indicative of the significant level of protection on the membrane lipids. This may be attributed to ability PEPP to promote detoxification of reactive metabolites, which might have prompted and encouraged peroxidation of polyunsaturated lipids of the hepatoxic membrane (Sabiu et al., 2016).

Apart from the fact that histopathological examination complements with biochemical analyses, the hepatotoxic effects induced by $\mathrm{CCl}_{4}$ administration was also evident revealing extensive hepatocellular degeneration and loss of integrity of the hepatocyte. In contrast, histological results showed that treatment with a polyphenolic extract of Paullinia pinnata effectively ameliorated $\mathrm{CCl}_{4}$-induced hepatic toxicity. This result is in agreement with that of Venkatanarayana et al. (2012). However, following the administration of PEPP, the hepatocytes showed close to normal cellular architecture which may be as a result of regeneration and repair of liver cells (Etim et al., 2008; Emeka and Obioa, 2009). In line with these findings, it was obvious that histopathological examinations concur with observed biochemical analyses. The current observation has been previously touted by Adewale et al. (2014) and Wu et al. (2017) where administration of plant extract restored the efficiency of serum enzymes and liver histological architecture prompted by $\mathrm{CCl}_{4}$.

\section{Conclusions}

The present data showed that PEPP elicits effective protection against $\mathrm{CCl}_{4}$ induced hepatic damage by attenuation of oxidative stress and liver damage which thus lend credence to the potential of PEPP in amelioration of hepatic damage caused by $\mathrm{CCl}_{4}$ intoxication.

\section{References}

Adebayo JO, Yakubu MT, Egwin CE, Owoyele BV, Enaibe BU (2003). Effect of ethanolic extract of Khaya senegalensis on some biochemical parameters of rat kidney.Journal of Ethnopaharmacology 88:69-72.

Adewale OB, Adekeye AO, Akintayo CO, Onikanni A, Sabiu S (2014). Carbon tetrachloride (CCl4)-induced hepatic damage in experimental Sprague Dawley rats: Antioxidant potential of Xylopia aethiopica. The Journal of Phytopharmacology 3(2):118-123.

Aguirre L, Portillo MP, Hijona E, Bujanda L (2014). Effects of resveratrol and other polyphenols in hepatic steatosis. World Journal of Gastroenterology 20(23):7366-7380.

Akanji MA, Ngaha EO (1989). Effect of repeated administration of berenil on urinary excretion with corresponding tissue pattern in rats. Basic and Clinical Pharmacology and Toxicology 64:272-275.

Ali M, Qadir MI, Saleem M, Janbaz KH, Gul H, Hussain L, Ahmed B (2013). Hepatoprotective potential of Convolurulus arvensisagainst paracetamol-induced hepatotoxicity. Bangladesh Journal of Pharmacology 8:300-304.

American Liver Foundation (2017). The Liver Lowdown - Liver disease: the big picture. Retrieved March 122017 from http://wwwliverfoundation.org/education/liverlowdown/l1013/bigp icture.

Annan K, Dickson RA, Amponsah IK, Jato J, Nooni IK (2013). Pharmacognostic evaluation and physicochemical analysis of Paullinia pinnata L. (Sapindaceae). Journal of Pharmacognosy and Phytochemistry 2(2).

Balamuruganvelu S, Geethavani B, Premlal KR, Sengottuvelu S, Jaikumar S (2014). Hepatoprotective activity of Polyalthia longifolia leaves against paracetamol induced hepatotoxicity in rats. Scholars Journal of Applied Medical Sciences 2:908-910.

Beers RF Jr, Sizer IW (1952). A spectrophotometric method for measuring the breakdown of hydrogen peroxide by catalase. Journal of Biological Chemistry 195(1):133-140.

Boll M, Weber LWD, BeckerE, Stampf A (2011b). Pathogenesis of carbon tetrachloride-induced hepatocyte injury. Bioactivation of $\mathrm{CC} 14$ by cytochrome P450 and effects on lipid homeostasis. Zeitschrift fuir Naturforschung C 56(1-2):111-121.

Boll M, Weber LWD, Becker E, Stampfl A (2011c). Hepatocyte damage induced by carbon tetrachloride. Inhibited lipoprotein secretion and altered lipoprotein composition. Zeitschrift furr NaturforschungC 56:283-290.

Boll M, Weber LWD, Becker E, Stampll A (2011a). Mechanism of carbon tetrachloride-induced hepatotoxicity. Hepatocellular damage by reactive carbon tetrachloride metabolites. Verlag der Zeitschrift fur Naturforschung Tübingen 56:649-659.

Büyükbalci A, El SN (2008). Determination of in vitro antidiabetic effects, antioxidant activities and phenol contents of some herbal teas. Plant Foods for Human Nutrition 63(1): 27-33. 
Clawson GA (1989). Mechanism of carbon tetrachloride toxicity. Pathology and immunopathology Research 8(2):104-112.

Contreras-Zentella ML, Hernández-Muñoz R (2016). Is liver enzyme release really sassociated with cell necrosis induced by oxidant stress? Oxidative Medicine and Cellular Longevity 2016:3529149.

Danilewicz JC (2015). Folin-Ciocalteu, FRAP, and DPPH• assays for measuring polyphenol concentration in white wine. American Journal of Enology and Viticulture 66(4):463-471.

Doumas BT, Watson WA, Biggs HG (1971). Albumin standards and the measurement of serum albumin with bromcresol green. Clinica Chimica Acta 31(1):87-96.

Drury RAB, Wallington EA (1980). Preparation and fixation of tissues. In: Drury RAB, Wallington EA (Eds). Carleton's Histological Technique. 5.Oxford: Oxford University Press pp 41-54.

Emeka EJI, Obioa O (2009). Effect of a long term consumption of a diet supplemented with leaves of Gongronema latifolium Benth on some biochemical and histological parameters in male albino rats. Journal of Biological Sciences 9:859-865.

Etim O, Akpan E, Usoh I (2008). Hepatotoxicity of carbon tetrachloride: protective effect of Gongronema latifolium. Pakistan Journal of Pharmaceutical Sciences 21(3):269-274.

Fred-Jaiyesimi AA, AnthonyO (2011). Larvicidal activities of the extract and fractions of Paullinia pinnata Linn leaf. Pharmacognosy Communications 1(2):37-40.

Gill LS (1992). Ethnomedical uses of plants in Nigeria. Uniben Press BeninCitypp 82-83.

Jaeschke H, Knight TR, Bajt ML (2003). The role of oxidant stress and reactive nitrogen species in acetaminophen hepatotoxicity. Toxicology Letters 144(3):279-288.

Jaramillo-Juarez F, Rodriguez-Vazquez ML, Rincon-Sanchez AR, Consolacion M, Martinez GG, Ortiz J, Reyes JL (2008). Caffeic acid phenethyl ester against carbon tetrachloride toxicity in rats. Ann Hepatol 7:331-338.

Jimoh FO, Sofidiya MO, Afolayan AJ (2007). Antioxidant properties of the methanol extracts from the leaves of Paullinia pinnata. Journal of Medicinal Food 10(4): 707-711.

Khan RA, Khan MR, Sahreen S (2012). CCl-induced hepatotoxicity: protective effect of rutin on $\mathrm{P} 53, \mathrm{CYP} 2 \mathrm{E} 1$ and the antioxidative status in rat. BMC Complementary and Alternative Medicine 12(1):178.

Kim D, Lee CY (2002). Extraction and isolation of polyphenolics. In: Wrolstad RE, Acree TE, Decker EA, Penner MH, Reid DS, Schwartz SJ, Shoemaker CF, Smith D, Sporns P (Eds). Current protocols in food analytical chemistry. Supplement 6: I 1.2.1-I 1.2.12. Hoboken, NJ: Wiley.

Laight DW, Carrier MJ, Anggard EE (2000). Antioxidants, diabetes and endothelial dysfunction. Cardiovascular Research 47(3):457-464.

Lil JL, Stantman FW, LardyHA (1988). Antioxidant enzyme systems in rat liver and skeletal muscle. Archives of Biochemistry and Biophysics 263:150-160.

Ma JQ, Ding J, Zhang L, Liu CM (2014). Ursolic acid protects mouse liver against CCl4-induced oxidative stress and inflammation by the MAPK/NF-kappaB pathway. Environmental Toxicology and Pharmacology 37(3): 975-983.
Ma JQ, Li Z, Xie WR, Liu CM, Liu SS (2015). Quercetin protects mouse liver against $\mathrm{CCl}(4)$-induced inflammation by the TLR2/4 and MAPK/NF-kappaB pathway. International Immunopharmacology 28(1):531-539.

Mahmud ZA, Bachar SC, Qais N (2012). Antioxidant and hepatoprotective activities of ethanolic extracts of leaves of Premna esculenta Roxb. against carbon tetrachloride- induced liver damage in rats. Journal of Young Pharmacists 4(4):228-234.

Mallhi TH, Abbas K, Ali M, Qadir MI, Saleem M, Khan YH (2014). Hepatoprotective activity of methanolic extract ofMalva parvifloraagainst paracetamol-induced hepatotoxicity in mice. Bangladesh Journal of Pharmacology 9:342-346.

MansourSA, Mohamed RI, Ali AR(2017). Ameliorating effect of selenium against deltamethrin induced hepato-renal dysfunction and oxidative stress to pregnant rats and their offspring. Journal of Toxicology and Pharmacology 1:002.

Marklund S, Marklund G (1974). Involvement of the superoxide anion radical in the autoxidation of pyrogallol and a convenient assay for superoxide dismutase. The FEBSJournal 47(3):469-474.

Moore KL, Dalley AF (1999). Clinical oriented anatomy (4th ed). Lippincot Williams and Williams; a Woller klumner Corporation, Philadelphiapp 263-271.

Murugesan GS, Sathishkumar M, Jayabalani R, Binupriya AR, Swaminathani K, Yuri SE (2009). Hepatoprotective and alterative properties of kombucha tea against carbon tetrachloride-induced toxicity. Journal of Microbiology and Biotechnology 19(4):397-402.

Niki E (2009). Lipid peroxidation: physiological levels and dual biological effects. Free Radical Biology and Medicine 47(5):469-484.

Ogeturk M, Kus I, Colakoglu N, Zararsiz I, Ilhan N, Sarsilmaz M (2005). Caffeic acid phenethyl ester protects kidneys against carbon tetrachloride toxicity in rats. Journal of Ethnopharmacology 97:273-280.

Patrick-Iwanyanwu K, Ogwe G, Onwuka F(2010). The hepatotoxic effect of water soluble fraction of spent lubricating oil in Wistar albino rats. The Internet Journal of Toxicology 7(2).

Plummer DT (1978). In: An introduction to practical biochemistry (2nd ed), McGraw-Hill,London pp 144145.

Reilly CA, Aust SD (2001). Measurement of lipid peroxidation. Current Protocols in Toxicology 2(4):2-4.

Reitman S, Frankel S (1957). A colourimetric method for determination of serum glutamate-oxaloacetate and pyruvate transaminase. American Journal ofClinical Pathology 28:56-59.

Sabiu S, O’Neill FH, Ashafa AOT (2016). Zea mays, Stigma maydis prevents and extenuates acetaminophen-perturbed oxidative onslaughts in rat hepatocytes. Pharmaceutical Biology 54(11):26642673.

Sabiu S, Sunmonu TO, Ajani EO, Ajiboye TO (2015). Combined administration of silymarin and vitamin $\mathrm{C}$ stalls acetaminophenmediated hepatic oxidative insults in Wistar rats. Brazilian Journal of Pharmacology 25:29-34.

Szasz G (1974). Methods of enzymatic analysis. (2nded).

Schmidt E, Schmidt FW (1963). Determination of serum GOT and GPT. Enzymologia Biologica et Clinica 3:1.

Sheehan M, Haythorn P (1979). Predictive values of various liver function tests with respect to the diagnosis of liver disease. Clinical Biochemistry 
86

12(6):262-263.

SherlockS (1951).Liver disease. Journal of Biochemistry 297:204279.

Somnath D, Suresh R, Murali A, Babu SS, Aneela S (2017). In-vivo hepatoprotective activity of methanolic extracts of Sphaeranthus amaranthoides and Oldenlandia umbellate. Pharmacognosy Journal 9(1):98-101.

Szymonik-Lesiuk SM, Czechowska M, Stryjecka-Zimmer M, Somka A, Madro K, Celiski M, Wielosz M (2003). Catalase, superoxide dismutase, and glutathion peroxidase activities in various rat tissues after carbon tetrachloride intoxication. Journal of Hepato-Biliary-Pancreatic Sciences 10(4):309-315.

TamokouJD, Chouna JR, Fischer-FodorE, Chereches G, Barbos O (2013). Anticancer and antimicrobial activities of some antioxidant-rich cameroonian medicinal plants. PLoSONE 8(2):e55880.

Tietz NW (1995). Clinical guide to laboratory tests (3rd ed). WB Saunders Company, Philadelphia.

Tipoe GL, Leung TM, Liong E, So H, Leung KM, Lau TY, Tom WM, Fung ML, Fan ST, Nanji AA (2006). Inhibitors of inducible nitric oxide $(\mathrm{NO})$ synthase are more effective than an $\mathrm{NO}$ donor in reducing carbon-tetrachloride induced acute liver injury. Histology and Histopathology 21:1157-1165.

Umer S, Asres K, Veeresham C (2010). Hepatoprotective activities of two Ethiopian medicinal plants. Pharmaceutical Biology 48(4):461-468.

Venkatanarayana G, Sudhakara G, Sivajyothi P, Indira P (2012). Protective effects of curcumin and vitamin $\mathrm{E}$ on carbon tetrachlorideinduced nephrotoxicity in rats. EXCLIJournal 11:641-650.
Wright PJ, Plummer DT, Leathwood PT (1972). Enzyme in rat urine alkaline phosphatase. Enzymologia 42:317-327.

Wright PJ, Plummer DT (1974). The use of urinary enzyme measurements to detect renal damage caused by nephrotoxic compounds. Biochemical Pharmacology 23(1):65-73.

Wu T,LiJ,LiY,Song H (2017). Antioxidant and hepatoprotective effect of swertiamarin on carbon tetrachloride-induced hepatotoxicity via the Nrf2/HO-1 pathway. Cellular Physiology and Biochemistry 41(6):2242-2254.

Yakubu MT, Bilbis LS, Lawal M, Akanji MA (2003). Evaluation of selected parameters of rat and kidney function following repeated administration of yohimbine. Biokemistri 15(2):50-56.

Yoshida Y, Umeno A, Shichiri M (2013). Lipid peroxidation biomarkers for evaluating oxidative stress and assessing antioxidant capacity in vivo. Journal ofClinical Biochemistry and Nutrition 52(1):9-16.

Yusuf A, Zakir A, Shemau Z, Abdullahi M, Halima SA (2014). Phytochemical analysis of the methanol leaves extract of Paullinia pinnata Linn. Journal of Pharmacognosy and Phytotherapy 6(2):10-16.

Zamble AMS, Carpentier M, Kandoussi A, Schpaz S, Petrault O, Ouk U, Hennuyer N, Fruchert JC, Staeles B, Bodret R, Duriez P, Baillent FJ (2006). Paulina pinnata extracts rich in polyphenols, promote vascular relaxation via endothelium-dependent mechanisms. Journal of Cardiovascular Pharmacology 47(4):559-608. 